\title{
Social Policy Experience In Indonesia: Case Study On Unconditional Cash Transfer Program
}

\author{
Yogi Suprayogi Sugandi ${ }^{1}$
}

\begin{abstract}
:
This Article is intended to the poverty incidence that occurred in Indonesia in 2005 and 2008 as the impact of rising world oil prices that led to the unconditional cash transfer program UCT (Bantuan Langsung Tunai (BLT) i.e Indonesia literate) was launched in Indonesia. BLT program is one program that was launched by the Indonesian government in early 2005 and mid 2008. Unconditional cash transfer program is one of the social policy given to the poor as a way to reduce the impact of rising world oil prices that could affect the purchasing power of the poor in Indonesia. This program circulate the money of approximately US\$10/month is regarded as an aid that is "giving charity" to the poor in Indonesia. This article also will show some of the BLT program as one of the social policy in Indonesia. The various obstacles encountered during this policy and also some economic and social problems encountered in this program, starting from the problems of counting the poor community, the implementation of the program until the end of this BLT program. This will be a descriptive writing by describing a variety of archival and field data the government and conducted by the author. It is to intended the readers to know how social policy was implemented in Indonesia as an experience.
\end{abstract}

Key Words: Unconditional Cash Transfer Program, Poverty and Social Policy.

\section{A. Introduction}

The human beings being the superior of all the creations are supposed to act the vicegerents (Khalifah in Arabic literate) i.e. the representatives on this earth. Human has right to survive physically with biological and all other need-fullfilling things to lead a comfortable life in this world. He must be capable of working physically after he enters the adulthood proxied by labour force in conventional wisdom. Hence, the protection of life and property, faith, honour and dignity and the ability to contribute to the future progene through pro creation after marriage are the most essential requisites of human existence in this world.

The World Bank's two decades ago has launched "Assault on World Poverty" notably announced by World Bank president's Robert Mac-Namara and now community of the world introduced by new concepts for human develop-

\footnotetext{
${ }^{1}$ Lecturer of University of Padjadjaran Bandung, Indonesia. Email : yogi.suprayogi@unpad.ac.id
} 
ment program, we call it MDGs (Millenium Development Goals) to reducing poverty by half by the year 2015, among these policies and strategies micro-finance proved to be the most useful mechanism in poverty alleviation adopted by both developed and developing countries today.

Poverty alleviation or solving the poverty problem in low-income countries is becoming a world wide issue today - it requires rapid growth in output, income and employment. But where is the effective demand for massive increases in output to come from? Domestic demand has traditionally been important in the initial stage of accelerated economic growth. But kick -starting domestic demand necessitates rising productivity in the large agricultural sector and creating more employment, increasing income and larger marginal marginal proppensity to consume (MPC) through integrated approach of physical investment and human capital (Wan Sulaiman wan yusoff, $2007: 1$ ).

The eradication of poverty is essential for sustainable human settlements. The principle of poverty eradication is based on the framework adopted by the World Summit for Social Development and on the relevant outcomes of other major United Nations conferences, including the objective of meeting the basic needs of all people, especially those living in poverty and disadvantaged and vulnerable groups, particularly in the developing countries where poverty is acute, as well as the objective of enabling all women and men to attain secure and sustainable livelihoods through freely chosen and productive employment and work." Commitments to poverty alleviation are dispersed throughout the Habitat Agenda in Chapter III entitled Commitments (sections on Adequate Shelter for All, Sustainable Human Settlements, Enablement and Participation, and Financing Shelter and Human Settlements). In its commitments, the Habitat Agenda also addresses the above three aspects of poverty.

Besides MDG's, nobel price winner in 2006 is Professor Muhammad Yunus has successfully demonstrated by the institutions called the Grameen Bank of Bangladesh (bank for the poor) with a unique policy of trust rather than collateral-based small loans. Only policy of empowerment and capacity-building can prepare an individual to fulfil his obligations to himself, the community/society/state and finally the Creator.

The World Bank, in 1988 estimated that the urban poor accounted for 25 percent of the urban population in the Third World or 330 million individuals (World Bank: 1990). Indeed, as a result of continuing urban growth by the year 2000 the majority of the world's absolute poor

Table 1

Poverty Line, Number, and Percentage of Poor People, 2004-2009

\begin{tabular}{|l|l|l|l|l|l|l|l|l|}
\hline Year & \multicolumn{2}{|c|}{$\begin{array}{c}\text { Poverty Line } \\
\text { (rupiahs) }\end{array}$} & \multicolumn{3}{c|}{$\begin{array}{c}\text { Number of Poor People } \\
\text { (million) }\end{array}$} & \multicolumn{3}{c|}{ Percentage of Poor People } \\
\hline & Urban & Rural & Urban & Rural & Urban+Rural & Urban & Rural & Urban+Rural \\
\hline 2004 & 143,455 & 108,725 & 11.40 & 24.80 & 36.10 & 12.13 & 20.11 & 16.66 \\
\hline 2005 & 150,799 & 117,259 & 12.40 & 22.70 & 35.10 & 11.68 & 19.98 & 15.97 \\
\hline 2006 & 174,290 & 130,584 & 14.49 & 24.81 & 39.30 & 13.47 & 21.81 & 17.75 \\
\hline 2007 & 187,942 & 146,837 & 13.56 & 23.61 & 37.17 & 12.52 & 20.37 & 16.58 \\
\hline 2008 & 204,896 & 161,831 & 12.77 & 22.19 & 34.96 & 11.65 & 18.93 & 15.42 \\
\hline 2009 & 222,123 & 179,835 & 11.91 & 20.62 & 32.53 & 10.72 & 17.35 & 14.15 \\
\hline
\end{tabular}

Source: Statistical Yearbook of Indonesia 2009: Based on National Socio Economic Survey 
will live in urban areas (Wratten, E: 1995). From so many evidence in Asia, Africa and Latin America that the urban poor have suffered disproportionately from the adjustment process. This due to: changes in prices (and a reduction in subsidies), in particular increases in food process and service charges; restriction on wage levels and reduction in employment; and cuts in public expenditure (health and education) and urban
(Poverty Limited Income) has been increased in early 2006, and become one of the topic's whose announcing by President of Indonesia Susilo Bambang Yudhoyono by the ends of august 2006. In this situation could seen there is increasing of total urban poverty is 3.95 million people was poor. But in these statistic, urban poverty not appear to be an urgent issue in Indonesia if we compared with rural statistic in

Figure 1

Proportion of Population Below Minimum Level of Dietary Energy Consumption

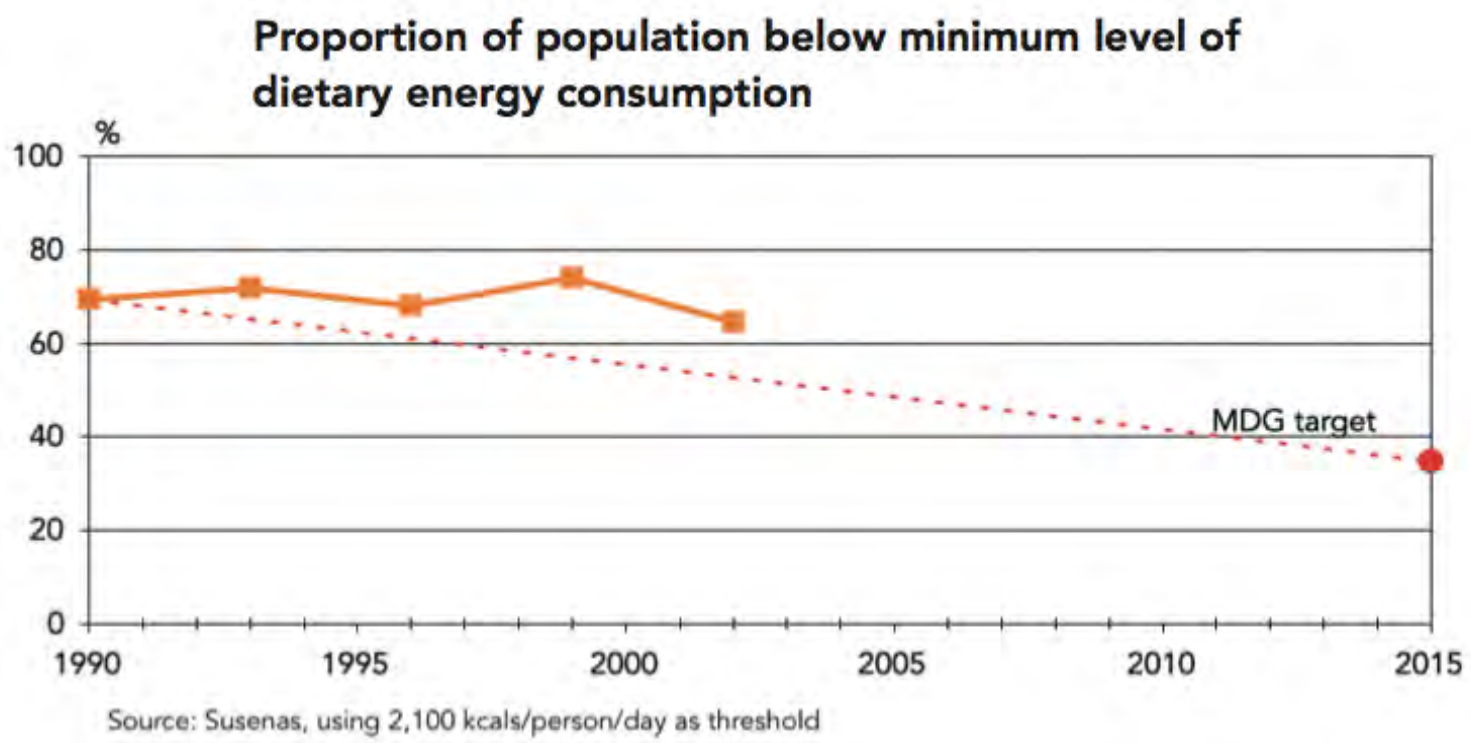

infra-structure expenditure (Holland, J: 1994).

Indonesia was one of development country and most of the population were poor if we use US\$ 2 indicator (World Bank's note) more over than Indonesian people's is poor. When 1998 most of Asia countries got financial crisis, impact of this economic crisis make Indonesia become one of poor country. Urban poverty in Indonesia become one of the largest when the impact of financial crisis still sustain in Indonesia land. The different of poverty between urban dan rural could see from the table below.

Urban poverty in Indonesia population in 1996 was increased from 9.42 million to 17.6 million in 1998, and from last information from BPS (central of statistic bureau) of March 2006 increased again to 12.40 million but in percentage become lower $(12.13 \%$ in year 2004 and ends of March 2006 is $19.51 \%$ ) because PLI view years. However, there are a number of reasons why it is important that the problem of urban poverty be revisited, the most recent being the current governments's desire to eradicate poverty altogether. The number of people in Indonesia living below the poverty line decreased from 39.30 million in 2006 to 32.53 million people in 2009. The declining rate of poverty was in part a result of the economic growth attained during the period.

The proportion of the population below the minimum level for adequate dietary energy consumption is still high in Indonesia. Twothirds of the population still consumes less than $2,100 \mathrm{kcal}$ a day.

Income disparity in Indonesia, as measured by the Gini Index (which measures income inequality) was relatively small during 2005-2007. The table below, using the Gini Index, 
shows that income disparities in rural areas are lower also come in the form of social assistance such as the than in urban areas.

program for Social Health Security (Jaminan

Table 2

Distribution per Capita Expenditure and Gini Index 2005-2009

\begin{tabular}{|c|c|c|c|c|c|}
\hline Region & Year & $\begin{array}{l}40 \% \quad \text { Low } \\
\text { Expenditure }\end{array}$ & $\begin{array}{l}\text { 40\% Medium } \\
\text { Expenditure }\end{array}$ & $\begin{array}{l}20 \% \text { High } \\
\text { Expenditure }\end{array}$ & $\begin{array}{l}\text { Gini } \\
\text { Index }\end{array}$ \\
\hline \multirow{5}{*}{ Urban } & 2005 & 21.16 & 37.24 & 41.60 & 0.32 \\
\hline & 2006 & 20.54 & 36.58 & 42.88 & 0.32 \\
\hline & 2007 & 18.27 & 37.83 & 43.90 & 0.36 \\
\hline & 2008 & 19.41 & 37.09 & 43.50 & 0.35 \\
\hline & 2009 & 19.93 & 36.89 & 43.18 & 0.37 \\
\hline \multirow{5}{*}{ Rural } & 2005 & 23.41 & 40.04 & 36.55 & 0.27 \\
\hline & 2006 & 24.03 & 39.54 & 36.43 & 0.26 \\
\hline & 2007 & 22.43 & 39.11 & 38.46 & 0.29 \\
\hline & 2008 & 22.52 & 39.99 & 37.49 & 0.29 \\
\hline & 2009 & 23.30 & 38.58 & 38.12 & 0.29 \\
\hline \multirow{5}{*}{ Total } & 2005 & 20.22 & 37.69 & 42.09 & $\mathbf{0 . 3 3}$ \\
\hline & 2006 & 19.75 & 38.10 & 42.15 & 0.33 \\
\hline & 2007 & 19.10 & 36.11 & 44.79 & 0.36 \\
\hline & 2008 & 19.56 & 35.67 & 44.77 & 0.35 \\
\hline & 2009 & 21.22 & 37.54 & 41.24 & 0.37 \\
\hline
\end{tabular}

Source: Statistics Indonesia 2009

The Government of Indonesia is determined to further reduce the number of people below the poverty line through various government intervention programs designed to meet the basic needs of the people. Such programs include: 1) Provision of subsidies (such as subsidies for food, fertilizer, and loans), which can
Kesehatan Masyarakat /Jamkesmas), the School Operational Assistance (Bantuan Operasional Sekolah/BOS), and the Family Hope Program (Program Keluarga Harapan/ $\mathrm{PKH}$ ), the credit guarantee fund/financing for micro, small, and medium business entities (Usaha Mikro, Kecil dan Menengah/UMKM) and cooperatives, and through the Smallholder Loan Program (Kredit Usaha Rakyat/KUR); 2) by facilitating and expanding business opportunities through eliminating various levies that have arisen in selected regions due to reform and decentralization, Program Keluarga Harapan $(\mathrm{PKH})$ or the Family Hope Program is a Government's scheme that is intended to help families particularly those in extreme poverty through providing cash-assistance should they meet the requirements.

This programme is aimed at improving the quality of education and health of the very poor families. Currently, PKH has already been applied in twenty provinces, such as in West Nusa Tenggara and

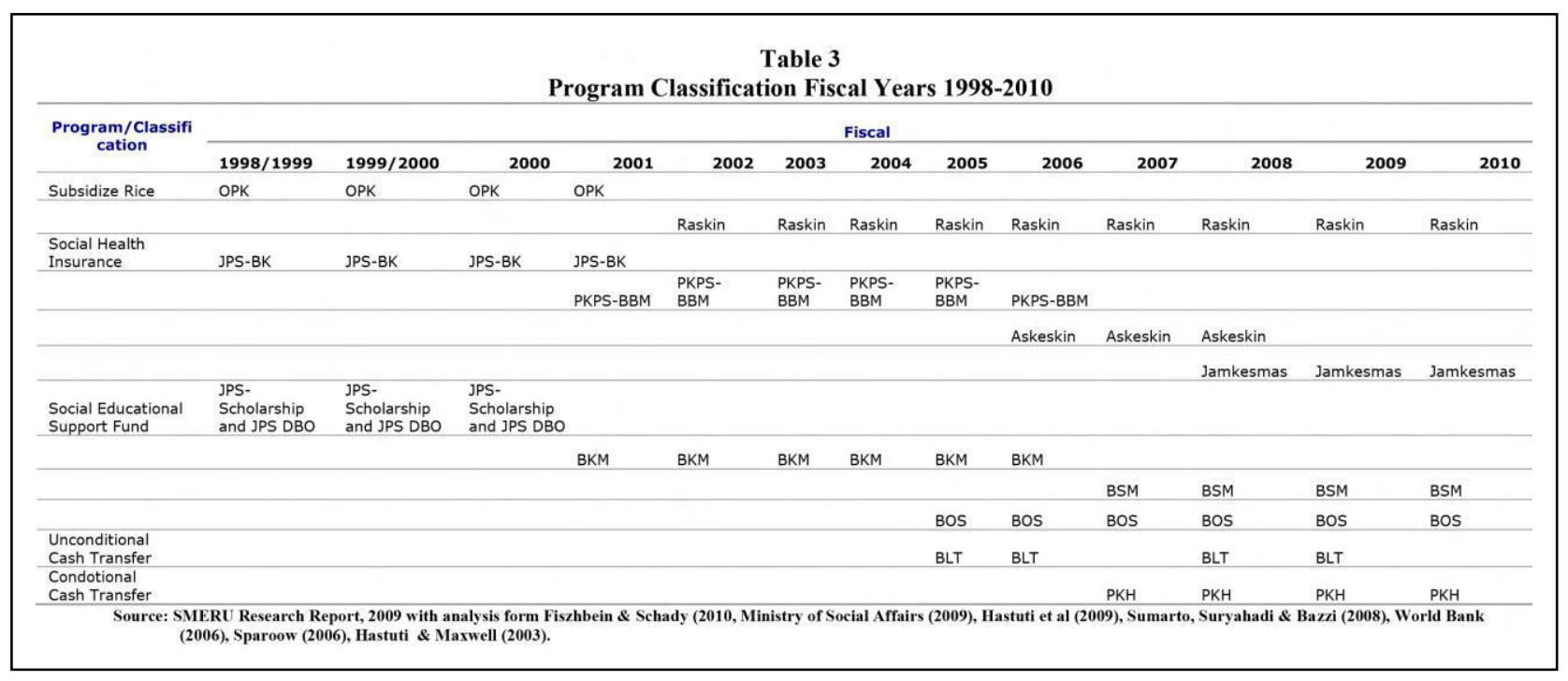


Gorontalo and Unconditional Cash Transfer (Bantuan Lang-sung Tunai/BLT) as part of the National Program for Self-Reliant Community Empo-werment (Program Nasional Pemberdayaan Masyarakat (PNPM).

\section{B. Cash Transfer Programme for the Poor in 2005 and 2008}

Until 2005, universal fuel subsidies dominated the government's social spending. Between 1998 and 2005, fuel subsidies averaged three-quarters of the total subsidies and transfers that constituted Indonesia's social protection system (World Bank, 2006).

Figure 2

Shows The Proportion

of Fuel Subsidy Compared to other

Social Spending from 1994/1995 to 2005 .

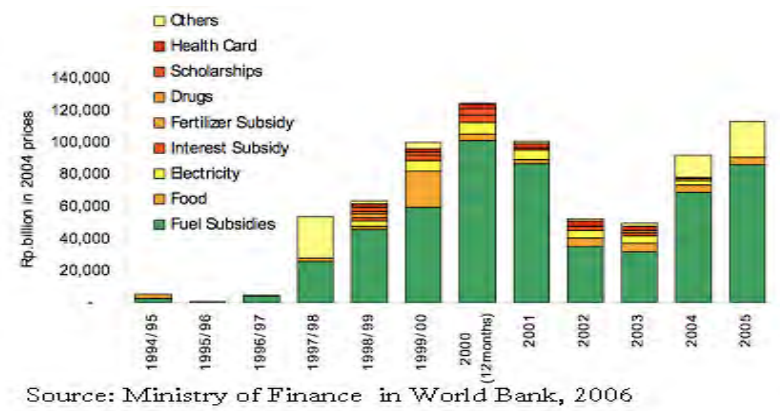

This subsidy, however, benefited more middle and higher income groups as they consume a lot more fuel than those in the lower group. As figure 3 shows, the benefits accruing to the top income quintile from fuel subsidies were more then five times those accruing to the bottom quintile. Only around Rp.5 trillion out of the total Rp.103 trillion spent on fuel subsidies in 2005 was absorbed by the poorest quintile and the top 40 percent captured 60 percent of the subsidy (World Bank, 2006).
Figure 3

Benefit of fuel subsidy by per capita expenditure decile

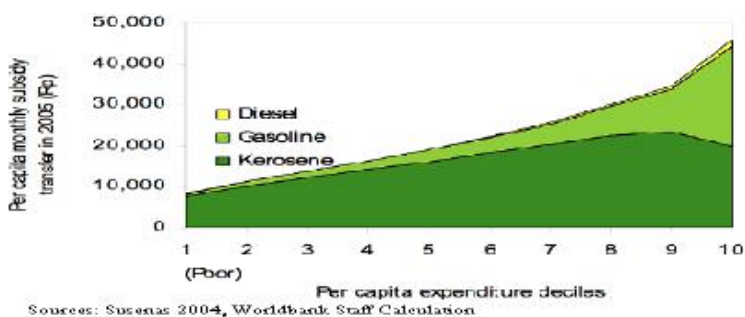

The government of Indonesia implemented an unconditional cash transfer (UCT) program in October 2005 in order to mitigate the impact of a removal of fuel subsidy in the same month. The program is targeted at 15 million poor households, determined by BPS (Statistics Indonesia) using a proxy means testing method. Each household receives Rp1.2 million for one year (roughly the country's current per capita GDP), which is disbursed quarterly in equal amounts.

It should be noted that the Ministry of Social Welfare (Depsos) considered that poverty was on the rise again in late 2005 in the wake of the major fuel price increases. It thought that the gradual downtrend of poverty visible in the BPS statistics up to 2004 would reverse in late 2005. It considered the cash transfer system to be a needed offset to this trend. The Ministry currently uses a poverty income guideline of Rp. 125,000 per person per month as a measure of the poorest of the poor, Rp. 150,000 for other poor, and Rp. 175,000 for the near poor. These guidelines would classify 15 million households containing over 60 million people as poor or near poor, representing about 28 per cent of the Indonesian population of nearly 220 million people.

On this basis payment of Rp. 100,000 per month to a poor family of 4 would raise their income by 16 to 20 per cent. Other that the regressive nature of fuel subsidy, the escalation of world oil prices and the lack of sustainability revealed by the fiscal outlook have led the government to change the policy. In 2005, amidst 
controversy, the government lifted fuel subsidy and consequently raised fuel prices by an average of 29 percent in March 2005 and another 114 percent in October 2005. By 2006, the government has saved an estimated US\$10.1 billion from the subsidy reduction (World Bank, 2006). A shift was then made to more targeted subsidies via health, education and rural infrastructure programmes. In this context, the switch to targeting conforms to all three features of policy environment from which the motivation for targeting arises mentioned by Coady et al (2007): 1) the desire to maximize the reduction in poverty or the increase in social welfare, 2) Budget constraint and 3) Opportunity cost or the tradeoff between the number of beneficiaries

\section{B.1 Cash transfer programme for the poor in 2005}

The second major initiative commencing in October 2005 was the issue of grants of Rp. 100,000 per month (US\$10) to households of poor and near poor families. The initial target was 60 million people in 15.5 million households, which was extended to more than 70 million people in 19.2 million households in the second round. The mechanism of this programme is described as follows. The poor are to be initially identified by local authorities and classified by economic level on the basis of 14 criteria developed by BPS (Statistics Indonesia) (See Box). Local authorities at the lowest level produce lists of households of people identified to be poor. These households are then visited by a BPS enumerator who helps them fill out the assessment form. This is then sent to the local BPS office where the forms are graded and a list of poor households is developed. This list is then supplied to the Post Office, while entitlement cards are issued to the households assessed as poor. Cash transfers are made via the BRI Bank to the Post Office, which in turn makes payments in quarterly lump-sums to the designated households. These must produce their BPS card to receive payment. Payments are made in lumpsums of three months allocation at a time.
14 Criteria for receiving cash transfers:

1. Size of House (square meters)

2. Flooring Material of House

3. Material used for Walls of House

4. Sanitary Facilities in house

5. Source of Drinking Water

6. Source of Main Lighting

7. Kind of Fuel used for daily cooking

8. Source of Main Lighting

9. How many times a week the family buy Meat/Chicken/Milk

10. How many times per day the family eat

11. How many new clothes the family buy for majority of members per year

12. Financial ability to go to clinic (Puskesmas) if sick

13. Main Job of Head of Family

14. Possession of specified assets worth over 500,000 rupiah

(Savings, Gold, Colour TV, Livestock)

This is a massive new undertaking which is likely to stretch the limits of the Indonesian administrative system. The cash transfers are estimate to cost 1.5 trillion rupiah (US\$150 million) per month. This unconditional cash transfer is a one-year programme. The government has allocated Rp. 23 trillion, of which Rp. 15 trillion is for the payment of the first three quarters (benefits and administrative costs) in 2005.

Regarding the effectiveness of this system, the following issues can be pointed out:

The accuracy of targeting, including poor people who miss out and leakages of assistance to non-poor people.

Whether there should be some extra conditionality on the eligibility of assistance, such as children attending school, and medical vaccinations achieved.

Tradeoffs between cash transfers and direct provision of services. The merits of a cash transfer approach as against the alternative of direct services delivery to the poor via health, education, and nutrition programmes. Whether payment should be made to the (usually male) Head of Family, or the mother of children in the household as has been the 
case with some of the Latin American cash transfer programmes (e.g. Mexico).

$\square \quad$ The administrative effectiveness of the scheme.

The fuel price increase obviously affects the economy, and inevitably the economy of the poor. The second price increase was considered to have affected the poor more than the first, not only because of the greater increase, but also because it included kerosene (which was excluded in the first), an oil product commonly used by poor households as an energy source for cooking. The World Bank's (2006) estimation pointed that "The total short term fuel price increase impact made up about 5.1 percent of per capita expenditure for the poorest decile and 6.2 percent of per capita expenditure for the richest decile. In the absence of any compensatory measures, it is estimated that the October price increase would have led to a 5.6 percentage point increase in poverty headcount index; other factors being constant".

To cushion the economy of poor and near-poor households against shocks resulting from the fuel price increase, the government for the first time implemented an unconditional cash transfer programme (Bantuan Langsung TunaiBLT). The BLT programme is intended to provide poor and near-poor households with immediate relief to cope with expenditure shocks resulting from the rise of fuel price. Beneficiary households, who were identified by the Indonesian Central Bureau of Statistics (BPS) using a proxy-means testing methodology, each receive Rp. 100.000 (equivalent to around US\$10) per month. The programme was designed for one year (October 2005-September 2006), and disbursements were made quarterly.

\section{B.2 Cash transfer programme for the poor in 2008}

In 2007, the (unconditional) cash transfer programme was replaced by a conditional cash transfer programme (Program Keluarga Harapan). In July 2007 the government launched pilot programmes in seven Provinces. The target groups are poor households with pregnant women and children between 0 and 15 years of ages. These households receive cash for a maximum period of six years. According to the BPS data, 6.5 million households are estimated to be in this category. The following Table shows the cash benefit of conditional cash transfer:

Table 4

Amount of conditional cash transfer programme. Cases Annual amount per household

\begin{tabular}{|l|c|}
\hline \multicolumn{1}{|c|}{ Cases } & $\begin{array}{c}\text { Annual } \\
\text { Ammount per } \\
\text { Household }\end{array}$ \\
\hline Fixed amount & $\mathrm{Rp} \mathrm{200,000}$ \\
\hline $\begin{array}{l}\text { a. Child below 5 of ages } \\
\text { b. Pregnant and feeding } \\
\text { mother }\end{array}$ & $\mathrm{Rp} 800,000$ \\
\hline \begin{tabular}{l} 
c. Child in primary school \\
\hline $\begin{array}{l}\text { d. Child in secondary school } \\
\text { Average amount per household }\end{array}$
\end{tabular} & $\mathrm{Rp} 1,3000,000$ \\
\hline $\begin{array}{l}\text { Minimum amount per } \\
\text { household }\end{array}$ & $\mathrm{Rp} 600,0000$ \\
\hline $\begin{array}{l}\text { Maximum amount per } \\
\text { household }\end{array}$ & $\mathrm{Rp} \mathrm{2.200,000}$ \\
\hline
\end{tabular}

Source: SMERU Research Report, 2009

In June 2008, amidst pressure of the global fuel price increase, the Indonesian government again reduced the subsidy for domestic fuel prices, which led to an increase of fuel price by around 28.7 percent (Tempo, 2008). A similar scheme tothat of the 2005 BLT is employed to mitigate the shock on the economy of the poor. The 2008 BLT targets the same number of people as 2005 (19.2 million households) and uses the same baseline data with some adjustments through a verification process. The amount of funds disbursed is also Rp. 100.000 per moth per 
beneficiary households, but it is provided for seven moths (June-December 2008) in two tranches: Rp.300.000 for June-August and Rp. 400.000 for September-December.

The objectives of the BLT programme, as stipulated in the Presidential Decree No. 3 of 2008 are as follows (Depsos, 2007):

$\circ$ To help the poor in maintaining the fulfilment of their basic necessities.

- To prevent the decline of welfare level among the poor resulting from economic hardships.

- To promote social responsibility and social awareness.

Unlike the previous programme, the receipt of the cash benefits is payable as long as certain conditions on health and education are met1. This programme has just started, hence feedback on its effectiveness is limited. However, issues expected to arise with respect to ILO include:

- It is expected that the accuracy of targeting will improve compared to the previous unconditional cash transfer programme. However, the impact of this conditional cash transfer programme should be evaluated carefully. The programme should be reviewed regularly in the light of the impact evaluation.

- A well-functioning monitoring system of conditionality is a key to the successful implementation of this programme. In particular, ILO's child labour monitoring system in Indonesia can serve for the monitoring of the school attendance in the education component.

- Given that the maximum duration of the conditional cash transfer programme is six years, it is important to develop a suitable exit strategy from the programme. As income from labour is considered to be most sustainable resource to meet the household's basic needs, linkage should be sought with ILO's work in enterprise development and skills development, such as small business development projects, youth employment projects and local economic development projects.

\section{Social Policy Briefs}

During the later 1960s and early 1970s social administration became influenced by a range of alternative approaches (cf. Atkin 1996), particularly the structural influences of Marxist and feminist writers. Policy intervention was deemed to have failed, for despite the rhetoric of the welfare state, poverty and inequality remained high. Theoretical writings sought to give social administration a more explanatory focus and move away from pathologising the failure of individuals and groups. These theoretical approaches eschewed piecemeal reform as merely alleviating symptoms without eliminating root causes. Instead, systems-level analysis explored structural and institutional sources of disadvantage. This occurred in a range of spheres: class (Ginsburg 1979, Gough 1979), gender (Finch and Groves 1983, Pascall 1986), race (Rex 1973, Cohen et al 1982), and later, age (Walker 1980, Phillipson 1982 and 1986), and disability (Oliver 1990, Morris 1991). These structural analyses (i.e. class, race, gender) had major impacts on social administration, with it making the change in name (if not completely in perspective) to social policy. Social policy analysis developed various mixes of theoretical and empirical analysis, which still encouraged accusations that approaches were either atheoretical and lacking explanatory power, or absolving responsibility for dealing with real issues and improving conditions. This (perhaps healthy) tension is maintained in contemporary social policy debates.

This position challenges the building blocks of social policy analysis, rooted as they are in the Enlightenment tradition of science, knowledge, rationality and progress. In terms of social policy concepts, notions such as family, individuality, collectivism, and the distinction between public and private space are revisited, contested and reconstituted. It is possible to situate this more fundamental challenge within wider theoretical debates around postmodernism, which can "best be defined as European culture's awareness that it is no longer the unquestioned and dominant culture of the world" (Young 
1990). Within New Zealand this deconstruction is part of the more fundamental project of decolonisation, which is an intellectual activity (how we think about our world), as well as how we act upon and change it. These new types of spaces for discussion might allow new kinds of questions to be asked and new kinds of futures articulated. Clearly, the agenda of indigenous peoples is not only to maintain cultural independence within the sovereign state and resist assimilation, but also to challenge the legitimacy of that state and that majority culture (Mulgan 1993). Thus, this position must be situated within discussions around the place of indigenous knowledge, sovereignty and control.

Social administration inquiry centred on discreet institutions of the post-war welfare state: the health services, education, income security, social services and housing. Welfare state institutions were seen as synonymous with social administration, and the achievement of wellbeing was equated with access to a range of services. Hence, institutions and pieces of legislation were described and documented, their implementation difficulties and deficiencies noted, and changes suggested. Social administration is paternalistic in its view of policy and citizens; power is seen as formal, institutional, and top-down, with decisions taken by a benign government attempting to rectify the socio-economically disadvantaged circumstances of individuals and groups.

Social administration may be considered a-theoretical or even anti-theoretical in its perspective, lacking analytical rigour and attempting to merely reduce symptoms of problems while ignoring causes. This is an overly pessimistic picture that ignores much that is of value within social administration; for example, its problem-solving approach and concern with real world issues. However, as a construction none of the assumptions of social administration should escape critical scrutiny. This hybrid of social administration is influenced by a range of ideas about the nature of knowledge, the process of social change, and ideas about policy making and democracy. At an epistemological level, social administrative approaches to policy studies hold that institutions could be reformed to good effect if we knew the "facts" and could present evidence about current ways of doing things. Incremental change will result once policy makers are aware of empirical evidence, and institutions will gradually evolve.

Social administration adopts a rational approach to problem solving, with social problems typically viewed as having an objective existence. Thus, problems exist, are identifiable, and are open to amelioration and alleviation (Marsh 1965, Brown 1969). As Brown writes: "social administration is concerned with social problems and [second] it is concerned with the ways in which society responds to those problems" (p.13). Absent from the social administration perspective are later critiques that suggest problems are social constructions which are created and exacerbated by societal influences and pressures (Holstein and Miller 1993, Sarbin and Kitsuse 1994).

The social administrative approach frequently blurs the distinction between descriptive and normative approaches to policy making, and there is a corresponding belief (or even faith) that change will, and should, occur once evidence is assembled. Intervention is perceived to be both desirable and achievable, and social democratic ideas are influential. Social administration had its heyday in the 1950s and 1960s and this optimism was indicative of the post-war period of increasing public expenditure, welfare state expansion, economic growth and full employment. These were halcyon days indeed, and progress appeared so significant in the Western world that some commentators hailed the "end of ideology" (Bell 1962). improvements in computer capacity. Social science research and investigation took place within a positivistic tradition of objective scientific investigation, with the emphasis on identifying and measuring the extent of "problems".

Our theory does not necessarily contradict a long tradition in the literature that emphasizes redistribution as a key political motive behind the welfare state (e.g., EspingAndersen 1990; Korpi 1983). Indeed, Meltzer 
and Richard's (1981) influential work on the median voter and government spending, which focuses on the redistributive aspect of social protection, emerges as a special case in our model. Given a particular composition of skills, workers with higher income are likely to demand less social protection than are workers with lower income. Our argument parts ways with the Meltzer-Richardm odel, however, because we explicitly recognize that social protection also has an insurance aspect (Moene and Wallerstein 2001; Sinn 1995) and that demand for insurance varies among workers according to their degree of exposure to labor market risks (Baldwin 1992). A critical point is that in our model exposure to risk is inversely related to the portability of skills The main purpose of the social policy was to mitigate the impact of fuel price increase, caused by the fuel subsidy reduction, on poverty. This is a case where social policy is to correct the 'diswelfares' that created by economic policy (Hill 2006, p. 7). The implication at process level is that government must ensure that the poor use the money for purchasing basic necessities or investing in any other productive activities. The poor should not merely save the money. Economic growth and job creation need the increase of aggregate demand which can be achieved through the increase of consumption and investment (Keynes 1936, p. 325).

The roots of social policy and social work lie in the Fabian reformist, social administrative tradition of the early twentieth century. As an area of inquiry or discipline it borrows from a range of disciplines, principally political science, economics, sociology, public administration and anthropology (Marsh 1965, Brown 1969).

\section{The Policy's Synchronisation to Indonesian Social Welfare System}

Indonesia cannot fit into three social welfare's regime as identified by EspingAnderson. The nearest regime might be the conservative where government is responsible to social welfare only when the market fails (residual), which social policy is delivered through targeted (instead of universal) program (Esping-Anderson 1990, pp. 18-29). However, there are 49.2 per cent of Indonesian citizens who do not have any health insurance (Kompas 2010). This means that state is not responsible when the market fails. That is because Indonesian public budget is limited to cover social welfare costs. In 2009, for example, total government revenue was only 16.1 per cent of national Gross Domestic Product (GDP) (Departemen Keuangan n.d., pp. 1-12). Furthermore, social policy in Indonesia is positioned to support economic development (Bappenas 2010, p. II.3-1). In 2009, social expenditures which include health, education, subsidies other than fuel, and social protection were just 6.8 per cent of GDP (Departemen Keuangan n.d., pp. 1-12; Departemen Keuangan 2007). Therefore, government's policy is always to keep tax low and allow people to spend their money for their own welfare. As a result, ratio of tax revenue to GDP was only 9.9 per cent compared to an average of 14.0 per cent among non-OECD countries in Asia (IMF 2008, p. 11). These characteristics match with 'productivist' or East Asian model (Holiday 2000, p. 709; Jacobs 2000, pp. 2-4; Aspalter 2006, p. 297). However, compared to other East Asian countries, Indonesia has the highest corruption rate. The corruption perception index was 2.4 in 2008, in contrast to South Korea, for example, which was 5.6 (Transparency International 2009, pp. 397400). This makes Indonesian government more difficult to create social welfare.

Indonesian social welfare characteristic calls for a process implication to improve social solidarity and private sector participation on poverty mitigation. In 2005, poor households only received IDR300,000 which was equal to around US\$30 (Widjaja 2009, p. 3). That might be sufficient to help the near-poor to improve their purchasing power, but the amount was too small for the poor. Social solidarity will improve the social safety net of the poor. Private sector, through corporate social responsibility, should participate by improving poor people livelihood. For example, they can help to grow small scale and micro entrepreneurs which could create jobs at micro level. 
In the long term, as an implementation implication, government must create more jobs in formal sector. In 2006, there was more than 50 per cent of Indonesian worked in informal sector (Hermanto et al. 2010, p. 5), which most of them did not pay income tax. This makes government revenue become small, not only because the low tax, but also because the number of tax payers are small. Government believed that there were about 25 to 30 million more people are eligible to pay taxes out of 6 million that have been registered by 2008 (The Jakarta Post 2008).

Key Actors and Their Roles At political decision level, the key actors were the President with support from the Ministers of Finance, Social Welfare, and Energy. Their roles were to initiate and make a final and official decision of the policy. All of them are politicians with strong interests on political gain. As a process implication, it needs checks and balances procedure on political decision process. Other political interest groups and independent experts must involve in decision making process. Without check and balance, the ruling party in government could be just prioritize the urban poor and neglect the poor households in remote area. By doing so, the ruling party could have political gain from the majority of the poor, and at the same time possible to alleviate poverty. This would satisfy their political interest. The implementation implication is that government must consult public sector and support their UCT policy by scientific evidence; for example, reliable poverty data. This is in line with what Jeremey Bantham called 'expert bureaucracy' (Bessant et al. 2006, p. 15).

At implementation level, the key actors were Ministry of Social Welfare (DEPSOS), BPS, post office, and village officers. The DEPSOS played a central role in the implementation as it is they who manage the UCT budget, prepare the guidelines, coordinate other actors, and presents the accountability report. BPS was important to produce accurate 'poor household' list. Post office carried out a significant role by checking accuracy of BPS data, distributing the household poor cards (the card) and undertaking payment. Village officers were, in many cases, the key figures who determined the success and failure of the implementation. That is because the accuracy of 'poor household' list depended on them as they help BPS and post office officers on field investigation and data verification. In addition, village officers' role was also important in organizing cash collection in remote areas.

The implementation implication of including DEPSOS is to attain support from the local government for ensuring the performance of village officers. Under decentralization policy, DEPSOS has limitation in controlling implementation at field level. They just can rely on local governments because of decentralization. There are 584 local governments in Indonesia and the leaders not necessarily from the ruling party (Departemen Dalam Negeri 2010). Therefore, they need to have an effective coordinating and communication role. That creates a process implication, that is a need for a detail and clear implementation guidelines which organize all actors. The guideline must be able to help all actors from national to village level to perform their tasks well.

BPS needs additional enumerators due to the limitation of BPS officers. At the moment, number of BPS officers is only half of their need (BPS n.d.). That is still far than enough to conduct survey in around 72,000 villages (Kominfo-Newsroom 2009). If they rely on the village officer, the outcome could be biased because the village officers may have vested interest in selecting his or her relatives or prioritizing his or her ethnic group and neglecting others. However, the increase of the enumerator number is not enough. The process implication to ensure accurate data is a need of transparent and objective mechanism to determine the poor. If the reliable mechanism does not exist, there will be conflict and tension during implementation. This was happened during UCT implementation of 2005 where there were number of protests, threats to BPS and village officers, vandalism to public facilities, and conflict among villagers (Widjaja 2009, p. 12)

The process implication to allow post office to handover the cash is to have additional 
arrangement helping the poor from remote areas to pick up their cash. Post office branches are only available down to sub-district level. Without a different arrangement for collecting the cash, the value of the cash will be offset by the transport cost. DEPSOS reported that during the first instalment of 2005 eligible households received only 94.1 per cent of the total payment. In the second instalment it was only 89.6 per cent. One cause of the payment deduction was the payment cut did by village officers to cover the transport and fee cost to pick up the cash collectively (Departemen Sosial 2008b, p. 13). Furthermore, the post officers have no specialization on checking the accuracy of poor household list. Therefore, as an implementation implication, they need a special training on field verification.

An income level that is insufficient to supply minimum nutritional and basic non-food requirements (Barry. J.L., et al: 1997); poverty is often defined in terms of people who lived on less than $\$ 1.00$ per day ( $1 / 6$ of world population, about 1 billion people); but at the Earth Instute at Columbia University Researchers take a "human needs poverty" approach, by addresing its many causes: hunger, acces to health care and water, energy, trade barriers, gender quality, acces to education (Earth Institute, 22/12/2004). In view of concepts poverty is a multidimensional concept liked; lower income levels, food insecurity, terrible quality of life, landlessness/assetlessness, lack of human resource capacities, vulnerabilities and inability to cope, gender inequalities, human insecurity, lack of right to information and speech, last not the least lack of human rights.

But most of the definitions of poverty by economicts have defined it with respect to being able to attain a standard of living (Ravallion: 1994), poverty can be said to exist in a given society when one or more persons do not attain a level of economic well-being deemed to constitute a reasonable minimum by the standard of that society. The WDR (World Development Report) in 1990 defined poverty as "the inability to attain a minimal standard of living", or all households not able to achieve this critical level of consumption expenditure or income are described as poor. Based on Ravallion's definition of poverty who suggests that the concept of poverty or what poverty is, is very much determined by the norms, values and circumtances of the society in Indonesia, then it may be diffcult to conduct comparisons across countries and societies since the nature, structure of poverty may vary from one society to another. However, the word poverty can be divided into three different profiles: the poorest, best described as "the destitute poor", "the structural poor" and "mobile poor ", (Kozel, V: 1999).

\section{E. The Change Drivers}

The combination of oil price, government budget stability, and number of poor households will determine whether or whether not the UCT policy will be implemented again in the future. This indicates that the government must monitor all those variables. However, in the long term, government has to decrease the poverty at the level where public budget able to support the poor. In the case of fuel price subsidy, number of poor must be decreased significantly before government eliminate all fuel subsidies.

An election and other short term political interest could initiate the UCT policy because it can increase the popularity of the ruling party on poor people. This was the suspicion of the opposition parties when the UCT policy was enacted in 2009. This is not happened in Indonesia only, the conditional cash transfer policy in Mexico and Brazil were also used for political gain (Sewall 2008, p. 175). This creates a process implication to balance the power during decision making process as discussed previously. For long term purpose, the implementation implication is a need to improve the political awareness, particularly among poor people, so they aware that any kind of subsidy come from public budget, not from the politicians' pocket.

Availability of reliable socioeconomic data on individual citizens will increase the use of the cash transfer policy regardless of whether it is conditional or unconditional. Reliable data makes it easy to do eligibility testing. It may 
improve effectiveness of any social policy with targeting approach. Apart from several issues as discussed previously, The World Bank concludes that the UCT of 2005 was successful to mitigate the poverty (World Bank 2006, p. x). Cash transfer approach, as contrast to service provision approach such as free health care, is more effective to mitigate the short term impact of the increased fuel price (Yusuf \& Resosudarmo 2008, p. 45). The conditional cash transfer in Mexico and Brazil was successful to alleviate poverty in the short term, with potential for sustainable impact in the long term (Sewall 2008, p. 185). Moreover, economists have proved that income transfer will create more economic surplus than subsidy (Frank et al. 2009, pp. 181182). The wider use of (un)conditional cash transfer approach in social policy create a process implication; that is to strengthen the eligibility testing system which include a need of reliable data and information technology as well as a well-trained assessors and analysts. This also calls for an implementation implication where government must educate the recipients on how to use the cash in order to support the policy objective.

Other than the size involved, the lack of experience in cash transfers, both on the side of the implementers and beneficiaries, and the debates (mainly in the political arena) around moral hazards (laziness, dependency etc) of giving money to the poor have made the scheme arguably the most controversial to date. Oppositions of the policy expressed concerns over the negative side effect of cash benefit: the allegation that poor people can become dependent and lazy, which might cause a reduction in labour participation. If this effect does occur, the economy would suffer a loss in term of lower productivity, and the benefit can simply crowd out other coping mechanism that the communities would have employed without cash transfer (Darity, 1987; Grosh, 1993; Moffitt, 1992, 2003; Coady et al, 2004).

\section{F. Calculate Poverty For Implemented Programme}

In his paper "Poverty Alleviation: Pakistan's Experience" who presented in Center for Poverty and Development Studies University of Malay, july 2007, Kuala Lumpur, Malaysia, Muhammad Ayub Siddiqui write how to calculate poverty, there is some point to explain calculating poverty approach in many country:

\section{The Calorie Intake Approach}

Adequate is identified as satisfaction of nutrition/calorie requirements. Therefore, calorie requirements are suggested as the basis for defining a poverty criterion. Based on data from household income and expenditure surveys (HIES), consumption of food endowed with certain amount of calorie is calculated. Adequacy of calories is viewed as a standards of welfare and the most useful measure of absolute poverty (Ercelawn: 1990). The studies referred earlier calculated the amount of expenditures required to gain minimum amount of calories. Different studies used different minimum requirements of calories (Naseem: 1997) and accordingly the requirements of expenditure for these calories intake is different in different studies. Indonesia fistly used this approach to calculted poverty in era 1980-1995.

The problem with the calorie intake approach is that requirements of calories can not be generalized for all individuals and for all the regions. Calories requirements are different in different climatic zones (Sukhtame:1982 and Lipton: 1983). Setting up nutritional norms is basically the job of nutrional experts and they have tried to set up nutritional norms from time to time that would ensure normal health. Researchers have to rely on them and respect their judgments.

\section{The Basic Needs Approach}

In obtaining a poverty line, one typically construct a "food poverty line" which is based on some notion of minimum amount of money that 
a household needs to purchase some basic-needs food bundle. If cost of basic needs is estimated, then the food poverty line added to the non-food needs will equal the overall poverty line. This approach was used much earlier for the determination of poverty lines by Booth (1892), Rowntree (1892) and Orchansky $(1965,1968)$.

Ealry 1990 Indonesia become used Basic Needs Approach to calculated poverty. The used of this approaches is to easier calculated how many food and non-food which been expend per month per capita and per rupiah (Indonesia Money (US\$ $1=$ Rp. 9,000)).

\section{Relative Poverty}

Relative poverty line isn't fixed over the domain of poverty comparisons. Poverty line is related to averageincome or consumption in a country/religion of reference. This line in relation to the average standard of living of a particular society at a certain time chenges with the average earnings of the households. This approach may show a reduction in poverty when people's income may be falling all around. The following examples will illustrate relative poverty lines. The official poverty rate in the early 1990s was close to $15 \%$ in the United States and also close to $15 \%$ in (much poorer) Indonesia. Many of those counted as poor in the US would be considered to be comfortably well off by Indonesia standards. Amongst OECD/EU countries, the poverty line is often set at $50 \%$ of the median income in the country (or at $50 \%$ of the mean income). Relative lines are often used in richer countries.

For example (Yogi: 2006) make a research about comparative study at urban poverty in Bandung, Indonesia and Kuala Lumpur, Malaysia. He used different approach to know the poverty in this 2 countries. Indonesia usually used Basic Needs Approach and Malaysia used Relative Poverty to calculated they poor peoples.

Experience in many countries shows that urban development that merely focuses on the economic and physical situation without giving appropriate attention to human development such as poverty eradication and environmental management, will induce social and political problems throughout the whole region. Therefore, urban poverty eradication is essential, especially in a developing country like Indonesia, being a prerequisite in making major efforts to reform political life and to improve human development, good governance, economic structures and the judicial and legal system. In order to achieve successful development reforms, Indonesia has to be able to solve its poverty problems effectively. It should be based on careful analysis and detailed understanding of the underlying problems. Indonesia government also need to increase capacity in facilitating participatory processes involving the poor themselves, since in the past the government were better in working for the people and rather clumsy in working with the people.

In generally urban poverty in Indonesia can be separated into structural and transient characteristics. Structurally, urban poverty is related to socio-economic development and demography, while the transient characteristics relate more to the Indonesian crisi that began in 1997.

\section{G. Critized of Social Policy with BLT in Indonesia}

The implementation implication is a need to ensure that the cash go to right hand, and only the poor get the cash. Cash transfer has been practiced by developed countries where reliable household income data is available, however, in Indonesia, particularly during UCT implementation, this is not the case. Poor households determined by National Bureau of Statistics (BPS), field checked by post office officers and village officers (Departemen Sosial 2008a, pp. 10-31). Without reliable household income data, the BPS officers rely only on physical assessments such as quality of house, or merely on the judgement of village officers. This creates potential for under coverage where some poor households are not identified, and leakage where some ineligible households are included on the recipient list (SMERU 2006, p. 37). If the number 
of under coverage and leakage is high, the purpose of poverty mitigation will not be achieved. It is important for the government to classify the 'victims' of the increased fuel price. Those who suffer the most must be prioritized than the rest, and probably receive more cash. In the case of 2005 , urban poor had suffered the most because the kerosene price increase 185.7 per cent, which make it the highest compare to gasoline and diesel (Yusuf \& Resosudarmo 2008, p. 33). Urban poor rely on kerosene to fuel their stoves for cooking.

\section{Targeting}

- The proxy means testing is not localized enough as it is at the district level. Therefore, while it is able

○ to sufficiently identify poor districts and subdistricts, accuracy in identifying individual households is low.

- Data collection, which was designed as a census of the poor, is not implemented as such.

- The above condition results in $45 \%$ leakage (share of UCT going to non-poor households) and $45 \%$

$\circ$ undercoverage (share of poor households not receiving UCT).

- The suspect poverty indicators incited protests in several locations.

$\circ$ There is evidence of elite capture.

\section{Socialization}

- As a central government program, there is very little information given to local governments in terms

- of guidelines or informal notices.

- There is insufficient information disseminated to the public in terms of benefit, payment method,

- identification of beneficiaries, and complaint mechanism.

\section{Delivery}

- Delivery of the UCT card, which is needed to collect the transfer, differs by region.

- The problem with the UCT card is mainly in misprinting names or addresses of the beneficiaries.

- Disbursement of the transfers, meanwhile, is the best component of the UCT program.

- It is conducted at the post office, and there is virtually no case of post office officials pocketing a share

o of the transfer.

- Only those whose name is listed on the UCT card could receive the payment, but in some areas this condition is waived.

\section{Complaint Mechanism}

- There is some confusion as to which institution is responsible for accepting and taking action on complaints.

- Complaints are filed to the village office, which could not do much because it is not formally involved in the program.

- A circular from the Department of Home Affairs and the Office of the Coordinating Minister for Welfare required all district governments to receive the complaints. This circular, however, was largely ignored.

\section{Satisfaction of the Program}

- The FGD participants state that the weakest part of the program pertain to socialization and targeting.

- In contrast, the participants are very satisfied with delivery of both the UCT card and the payment.

- Convert the UCT to conditional cash transfer (CCT).

- The post office must be retained as the distributing institution of the program.

- The district and village-level governments should be given a role in the program in addition to being a complaint-receiving institution. This should be reflected in the budget allocation from the central government to the district governments.

- The criteria used to identify beneficiaries need to be improved and be more sensitive to local-specific conditions.

- These criteria of eligibility should be properly disseminated to the public to avoid jealousy and to increase community involvement in identifying inaccurate targeting. 
- Local governments, in coordination with the local BPS office, should be given the authority to withdraw UCT cards that are given to non-poor households.

- There should be a more intensive socialization of the program to the general public through the media.

\section{H. Conclusion and Recommendation}

This experience explores some number factors of failure of urban poverty alleviation program in Indonesia. There is some conclusion that is why need some extra studied especially for culture urban inhabitants to urban poverty.

The study strongly recommended some extra analized from Indonesian Government to deeply understanding what is urban poverty, because they characterized is very different from characterized rural's poverty. The strategy to alleviated should be improved not just used economic indicators but should used another indicator liked social, culture, political, business and technical skills.

\section{REFERENCES}

Andre Bayo Ala, 1981. Kemiskinan dan Strategi Memerangi Kemiskinan, Yogyakarta : Liberty.

Aspalter, C 2006, 'The East Asian welfare model', International Journal of Social Welfare, vol. 15, pp. 290-301.

Ariffin Jamilah, 1994. Poverty Amidst Plenty, Petaling Jaya, Selangor: Pelanduk Publications.

Arjan, de Haan, 1995. Bibliographical Review on Social Exclusion in South Asia, Discussion Paper Series No.79, Geneva: International Institute for Labour Studies.

Badan Pusat Statistik, 2007. Population of Indonesia. Result of the 2007 Population
Cencus. Series L.2.2. Jakarta : Badan Pusat Statistik,

Badan Pusat Statistik, 2006. Pedoman Penyandian Propinsi, Kabupaten/ Kotamadya dan Suku Bangsa. Sensus Penduduk 2007. [Coding Guides for Provinces, Regencies/Municipalities and Ethnic Groups. 2000 Population Cencus]. Jakarta : Badan Pusat Statistik,

Bessant, J, Watts, R, Dalton T \& Smyth, P 2006, Talking policy: how social policy is made, Allen \& Unwin, Sydney.

BPS, see National Statistics Bureau.

Bappenas, see Ministry of National Development Planning.

Badan Pusat Statistik, 2007b. Population of Jawa Barat. Result of the 2007 Population Cencus. Series L.2.2.14. Jakarta : Badan Pusat Statistik

Balogh, T., 1966. The Economics of Poverty, London: Weidenfeld and Nicholson Ungku Abdul Aziz,. 1964. "Poverty and Rural Development in Malaysia", Kajian Ekonomoi Malaysia, Vol.1, No.1, Jun.

Bappeda Kota Bandung, 2002, Evaluasi Perguliran Dana Program P2KP di Kota Bandung. Bandung, Bappeda.

Baum, W.C., 1990, Investasi Dalam Pembangunan : Pelajaran dari Pengalaman Bank Dunia 11, Cet 2, Jakarta : Universitas Indonesia.

Booth, S.R., 1901. Poverty: A Study of Town Life, London: Macmillan

Chamhuri Siwar dan Mohd Haflah Piei, 1988a. Dasar dan Strategi Pembasmian Kemiskinan - Kumpulan Rencana Tentang Kemiskinan, Kuala Lumpur: Dewan Bahasa dan Pustaka. 
Chamhuri Siwar dan Mohd Haflah, 1988b. Isu, Konsep dan Dimensi Kemiskinan (Kumpulan Rencana Tentang Kemiskinan), Kuala Lumpur: Dewan Bahasa dan Pustaka.

Chamhuri Siwar dan Mohd. Amin Mohd. Anuar, 1989. "Kemiskinan Di Kalangan Petani Padi: Kajian Kes Di Besut, Kemubu, Seberang Perai, Tanjung Karang dan Jasin", Penerbitan Tak Berkala No.38, Fakulti Ekonomi, Universiti Kebangsaan Malaysia, Bangi, Selangor.

Cueto, S 2009, 'Conditional cash-transfer programmes in developing countries', The Lancet, vol. 374, pp. 1952-1953.

Departemen Keuangan 2007, Data APBD tahun 2007 (Local government budget plan year 2007), Ministry of Finance of Republic of Indonesia, Jakarta, viewed 31 May 2010, .

n.d., Data pokok APBN 2005-2010 (Data base of national government budget plan of 2005-2010), Ministry of Finance of Republic of Indonesia, Jakarta.

Departemen Sosial 2008a, Petunjuk teknis penyaluran bantuan langsung tunai untuk rumah tangga sasaran (Technical guidance of unconditional cash transfer for targeted households), Ministry of Social Welfare of Republic of Indonesia, Jakarta.

Departemen Sosial 2008b, Efektifitas bantuan langsung tunai 2008 (Effectiveness of unconditional cash transfer of 2008), Ministry of Social Welfare of Republic of Indonesia, Jakarta.Diknas Kota Bandung, 1998, Kertas Kerja, "Perspektif Penduduk terhadap pengaruh Pendidikan Globalisasi”, Bandung, Kantor Pendidikan Nasional Indonesia.

Esping-Anderson, G 1990, The three worlds of welfare capitalism, Princeton University Press, Princeton NJ.Departemen Dalam
Negeri 2010, Basis data Depdagri (Database of Ministry of Home Affairs), Ministry of Home Affairs of Republic of Indonesia, Jakarta, viewed 30 May 2010,

Frank, A.G., 1973. "The Development of Underdevelopment", dlm. C.K. Wilber, ed., The Political Economy of Development and Underdevelopment, New York: Random House.

Friedmann, J., 1979. "Urban Poverty in Latin America - Some Theoretical Considerations", dalam Development Dialogue, Vol.1, April, ms 45-48

Frank, RH, Sarah, J \& Bernanke, BS 2009, Principles of microeconomics, 2nd edn, McGraw-Hill Australia, North Ryde.

George, V. dan I. Howards, 1991. Poverty Amidst Affluence - Britain and the United States, London, England: Edward Elgar.

IMF 2008, 'Tax administration reform and fiscal adjustment: the case of Indonesia (2001 07)', IMF Working Paper WP/08/129, International Monetary Fund, viewed 4 June 2010,.

Jacobs, D 2000, 'Low public expenditures on social welfare: do East Asian countries have secret?', International Journal of Social Welfare, vol. 9, pp. 2-16.

Keynes, JM 1936, The general theory of employment interest and money, Macmillan and Co, London.

Kominfo-Newsroom 2009, 'Menkominfo: tahun 2010 seluruh desa di Indonesia terkoneksi' (Minister of Communication and Information: all villages in Indonesia are connected by 2010), KominfoNewsroom, viewed 2 June 2010, .

Kompas 2010, 'Baru 50,8 persen masyarakat punya jaminan kesehatan' (It is only 50.8 
per cent of people with health insurance), Kompas.com, viewed 3 June 2010, . Harian Media Indonesia, 10 Juli 1999, Penduduk Miskin Indonesia.

Hermanto, B, Ali, AZ, Derina, R, Agus, AA \& Wibowo, SS 2010, 'Revitalising social security via growth in the micro insurance industry', Policy Briefs 11, Australia Indonesia Governance Research Partnership, Crawford School of Economic and Government, ANU College of Asia and the Pacific, The Australian National University, Canberra.

Hill, M 2006, Social policy in in the modern world: a comparative text, Blackwell, Malden, MA.

Holliday, I 2000, 'Productivist welfare capitalism: social policy in East Asia', Political Studies, vol. 48, pp. 706-723.

Jamasy, O., 2004, Keadilan, pemberdayaan dan penanggulangan Kemiskinan, Jakarta: Belantika.

Kamal Salih, 1983/1984. "Konsep, Definisi dan Pengukuran Kemiskinan", dlm. Institut Pertanian Malaysia (AIM), Kemiskinan Luar Bandar, Kuala Lumpur: AIM.

Kartasasmita, G., 1996, Pembangunan Untuk Rakyat : Memadukan Pertumbuhan dan Pemerataan, Jakarta : PT Pustaka.

Lewis, O., 1966. La Vida: a Puerto Rican Family in Culture of Poverty, San Juan and New York: Random House.

Ministry of National Development Planning 2010, Lampiran peraturan Presiden Republik Indonesia nomor 5 tahun 2010 tentang rencana pembangunan jangka menenangah nasional (RPJMN) tahun 2010-1014 (National medium development plan 2010-2014 appendix), Ministry of National Development Planning
(Bappenas), Jakarta.

Miller S.M. and W. Bloomberg Jr, 1970. "Shall the Poor Always be Impoverished", dlm. Warner Bloomberg, Jr., and Henry J. Schmandt, eds., Urban Poverty: Its Social and Poliitical Dimensions, California: Sage Publication, Inc.

Mohd Razali Agus, 2005, "Persetingganan di Malaysia: Penduduk dan Penempatan Semula", Kuala Lumpur: Penerbit Universiti Malaya.

Mohd Razali Agus, 2001, Perumahan Awam di Malaysia;Dasar dan Amalan Kuala Lumpur, Utusan Publication \& Distribution Sdn. Bhd.

Myrdal, G., 1970. The Challenges of World Poverty: A World Anti-Poverty Programme in Outline, New York: Vintage Books.

National Statistics Bureau n.d., 'Rencana strategis' (Strategic plan), Indonesian National Bureau of Statistics, Jakarta, viewed 3 June 2010, .

Nayak, P., 1995. Economic Development and Social Exclusion in India, Geneva: International Institute for Labour Studies.

Osman Rani Hassan dan Abdul Majid Salleh 1988. "Konsep-Konsep Kemiskinan dan Ketaksamaan: Satu Tinjauan", dalam Chamhuri Siwar dan Mohd Haflah, Isu, Konsep dan Dimensi Kemiskinan (Kumpulan Rencana Tentang Kemiskinan), Kuala Lumpur: Dewan Bahasa dan Pustaka.

Piachaud, D., 1987. "Problems in the Definition and Measurement of Poverty", Journal of Social Policy, Vol.16, No.2. ms. 147-164.

Rein, M., 1970. "Problems in the Definition and Measurement of Poverty", dlm. Peter Townsend, The Concept of Poverty: 
Working Papers on Methods of Investigation and Life-Style of the poor in Different Countries, London: Heinmann Educational Books Ltd.

Sewall, RG 2008, 'Conditional cash transfer programs in Latin America', SAIS Review, vol. 28, no. 2, pp. 175-187.

SMERU 2006, 'Kajian cepat pelaksanaan subsidi langsung tunai tahun 2005 di Indonesia: studi kasus di Provinsi DKI Jakarta' (Rapid assessment of unconditional cash transfer implementation of 2005 in Indonesia: a case study in the Province of DKI Jakarta), SMERU Research Report 361.05/DDC 21, SMERU Research Institute, Jakarta.

Scott, W., 1979. "Poverty Monitoring in Developing Countries", Development and Change, Vol.10, No.3, July.

Sen, A., 1981. Poverty and Famines: An Essay on Entitlement and Deorication, Oxford: Clarendon Press.

Sukmana, O., 2005, Sosiologi dan Politik Ekonomi, Malang, Jawa Timur: UMM Publication.

Surathman Kastin Hassan, 1996. "Kemiskinan dan Pembasmian Kemiskinan Mengikut Perspektif Islam", dlm. Chamhuri Siwar dan Nor Aini Hj Idris, sunt., Kemiskinan Dalam Pembangunan Ekonomi Malaysia.

Syed Othman Alhabsyi, 2000. "Solving Absolute Poverty Using answers Found in Religion", http://vlib.unitark11.edu.my/staffpublications/datuk.

Syed Othman Alhabsyi,1996. "Poverty Eradication From Islamic Perspectives", http://vlib.unitark11.edu.my/staffpublications/datuk, layari pada Ogos 2000.

Tim Persiapan P2KP, 1999, Manual Proyek
P2KP Buku Satu Pedoman Umum. Jakarta.

The Jakarta Post 2008, 'Tax office aims boost number taxpayers', TheJakartaPost.com, viewed 4 June 2010 , .

Transparency International 2009, Global corruption report 2009, Transparency International, Berlin, viewed 29 May 2010,

Townsend, P., 1979. Poverty in the United Kingdom - A Survey of Household Resources and Standards of Living, England: Penguin Books.

Winter, A.J., 1969. The Poor: A Culture of Poverty or a Poverty of Culture?, Michigan: William B. Eerdmans Publisher.

Widjaja, M 2009, 'An economic and social review on Indonesian direct cash transfer program to poor families year 2005', paper presented to Association for Public Policy Analysis and Management International Conference, Singapore, 7-9 January.

World Bank 2006, 'Making the new Indonesia work for the poor: overview', The World Bank, Jakarta, viewed 30 May 2010,

Yusuf, AA \& Resosudarmo, BP 2008, 'Mitigating distributional impact of fuel pricing reform: the Indonesian experience', ASEAN Economic Bulletin, vol. 25, no. 1, pp. 32-47. 